Prof. dr PREDRAG J. MARKOVIĆ, naučni savetnik

Institut za savremenu istoriju

Beograd, Trg Nikole Pašića 11

predragjmarkovic@yahoo.com

pregledni naučni rad

primljeno: 26. februar 2017.

prihvaćeno: 17. maj 2017.

\title{
ISTORIOGRAFIJA I SEKSUALNOST (POLNOST): SKICA ZA ISTORIJU JEDNE DISCIPLINE ${ }^{* 1}$
}

\begin{abstract}
APSTRAKT: U srpskoj istoriografiji, istorija seksualnosti (polnosti) razvila se unutar rodne istorije ( $\mathrm{z}$ zajedno sa njom). Uz nekoliko retkih izuzetaka, obe discipline su se pojavile devedesetih godina 20. veka. Što se tiče istorije seksualnosti, prvi talas radova se bavio medicinskim i zakonskim problemima, kao što su pobačaj, razvod i prostitucija. Sličan razvoj se može pratiti i u drugim istoriografijama. Ova tematska neravnoteža delom proizlazi iz prirode prvih otkrivenih izvora (dokumenti ustanova javnog zdravlja, sudova i policije). U 21. veku, istoriografija seksualnosti (polnosti) je procvetala, kao i istorija roda, a uostalom i sve druge vrste društvene istorije. Pojavili su se mnogi radovi posvećeni LBGTQ temama, posebno posle 2010. godine. Ipak, nedostaju sinteze iz ove oblasti.
\end{abstract}

KLJUČNE REČI: istoriografija, rodna istorija, seksualnost, metodologija

\section{Kratak pregled razvoja u svetu}

Seksualnost je srazmerno nedavno postala predmet posebne istoriografske discipline. Naravno, to ne znači da se nauka ranije nije bavila ovom oblašću ljudskog života. Njome se istoričari bave makar od renesanse, ali se kao posebno polje istoriografije pojavila kada i seksologija, u poslednjoj trećini 19. veka. Tada su seksolozi utvrdili značaj seksualnosti za život čoveka, a samim tim se postavilo i pitanje istorije ljudskih nagona. Mišel Fuko je čak tvrdio da je seksualnost dobila svoj „diskurs““ već od 17. veka. Kako god odredili početke izučavanja seksualnosti, bitno je istaći multi i interdisciplinarni karakter ovih istraživanja. Pre istoriografije, seksualnošću su se bavile mnoge naučne discipline. Tradicionalno, u izučavanju ljudske seksualno-

\footnotetext{
* Rad je deo projekta Konflikti i krize: saradnja i razvoj u Srbiji i regionu u 19. i 20. veku (47030) koji finansira Ministarstvo prosvete, nauke i tehnološkog razvoja Republike Srbije.

${ }^{1}$ Autor se koleba oko imenovanja. Antropolog Predrag Šarčević predlaže reč „polnost“ kao domaću reč, kao što su gender studies prevedene u studije roda. Uostalom, Žarana Papić među prvima koristi u naslovu jedne svoje knjige reč „polnost“. Videti: Žarana Papić, Polnost i kultura. Telo i znanje u socijalnoj antropologiji (Beograd: XX vek, 1997).
} 
sti su dominirali, još od kraja 19. veka, takozvani seksolozi, usredsređeni na seksualno ponašanje, a metodološki se uglavnom krećući unutar medicinskog modela istraživanja. Kasnije su se u proučavanje seksualnosti uključile i druge naučne discipline: psihologija (posebno socijalna), antropologija i to naročito istorijska antropologija, sociologija, filozofija, sociologija, istorija i teorija književnosti, istorija i teorija umetnosti, istorija i teorija popularne kulture, posebno filma. ${ }^{2}$

$\mathrm{Za}$ istoričare je po važnosti nadasve značajna društvena istorija i izrastanje istorije seksualnosti kao jedne od njenih mlađih poddisciplina, isprepletene sa drugim izdancima društvene istorije kao što su istorijska antropologija, istorija roda (gender history), istorija porodice i demografska istorija, kulturna istorija, istorija mentaliteta, istorija svakodnevnog života, pa donekle i ekonomska istorija.

Kao i za sve druge grane društvene istorije, francuski istoričari iz škole Anala, za koju mnogi teoretičari i istoričari istoriografije smatraju da je najznačajnija pojava u istoriografiji 20. veka, stoje na početku metodološkog i teorijskog utemeljenja i istorije seksualnosti, što sasvim logično sledi iz njihovog zanimanja za antropologiju, socijalnu psihologiju i „primitivni mentalitet“ (prvi analisti su čitali antropologa Levi-Brila) koje će kasnije prerasti u proučavanje istorije mentaliteta uopšte. ${ }^{3}$ Od analista je naročito značajan Žorž Dibi sa njegovim proučavanjem srednjovekovnog braka i odnosa polova. ${ }^{4}$

Sledeći podstrek za istoriju seksualnosti doći će iz „ženskih studija“ koje su same izrasle iz feminističkog pokreta u Sjedinjenim Američkim Državama (SAD) i Zapadnoj Evropi krajem šezdesetih i početkom sedamdesetih godina 20. veka. Uporedo sa borbom za prava žena u društvu i politici, počela je i borba za veće izučavanje žena u raznim društvenim naukama. Feministička istorija se borila za uvođenje žena $u$ istoriju, za otkrivanje njihove prošlosti, uporedo sa borbom za znanje, moć i jednakost u drugim oblastima života. Kao i u drugim oblastima života, i ova vrsta istoriografije je preokrenula stvari. Od početnog pitanja da li žene uopšte imaju istoriju, kojem je samom bila potrebna naučna legitimacija, došlo je, kako kaže Gizela Bok, do obrnute teze, da je istorija bez žena potpuno nemoguća. „Ženska istorija“ koja će kasnije prerasti u „rodnu istoriju“ pojačaće interesovanje za privatnu sferu, promeniće saznanja o istoriji rada, društvenih pokreta, mada u sebi krije opasnost ideološke i teorijske isključivosti, na šta ukazuju i Blek i Makrejld. Veoma važan doprinos feminističkih naučnica jeste i veći naglasak na novim istraživačkim metodama i predmetima istraživanja, jer su žene bile ,isključene iz istorije“ kako je to u naslovu svoje knjige istakla Šila Roubotam. Usmena (oralna) istorija je, na primer, dobila naročito važno mesto, budući da su žene, kao i ostali neprivilegovani delatnici $\mathrm{u}$ istoriji, ostavljale srazmerno malo tragova u tradicionalnim izvorima. ${ }^{5}$

${ }^{2}$ Michael L. Wilson, „Thoughts on the History of Sexuality“, The William and Mary Quarterly, LX, № 1, (2003), Sexuality in Early America, 193-196; John C. Fout, „A Note from the Editor“, Journal of the History of Sexuality, I, № 1, (1990), 1-2.

${ }_{3}$ Džeremi Blek i Donald M. Makrejld, Izučavanje istorije (Beograd: Clio, 2007), 86; Adam Kuper, Džesika Kuper, prir., Enciklopedija društvenih nauka (Beograd: Službeni glasnik, 2009), 24-25; Piter Berk, Istorija i društvena teorija (Beograd: Equilibrium, 2002), 23.

${ }^{4}$ Павле Миленковић, Школа Анала. Огледи о сочиолошкој историографији (Нови Сад: Stylos, 2004), 100-118.

${ }^{5}$ Dž. Blek, D. M. Makrejld, n. d., 177-180; Enciklopedija društvenih nauka, 1491-1492, 1560-1564. 
Monografije iz istorije seksualnosti pojavile su se u drugoj polovini sedamdesetih godina. Često su bile posvećene problemima koje je seksualnost izazivala u društvu, kao što su venerične bolesti, prostitucija, abortusi i seksualno nasilje, kao i alternativnim oblicima seksualnosti. ${ }^{6}$ Razvoj istorije seksualnosti možemo pratiti i preko radova u, koliko znamo, jedinom časopisu posvećenom istoriji seksualnosti, a to je Journal of the History of Sexuality, koji izdaje University of Texas već više od četvrt veka (ovom prilikom moram sa radošću da pomenem KOBSON sistem, koji mi je omogućio da pregledam skoro sve brojeve ovog časopisa). Za analizu su posebno zanimljivi specijalni tematski brojevi „Država, društvo i regulisanje seksualnosti u modernoj Evropi“ (dva broja, oktobar 1991. i januar 1992), „Lezbijske i gej istorije“ (dva broja, oktobar 1993. i januar 1994), „Seksualnost u kasnoj antici“ (julioktobar 2001), „Seksualnost i nemački fašizam“ (januar/april 2002), „Seksualnost i politika posle 1945. godine“ (april 2003), i „Proučavanje istorije seksualnosti: teorija, metode, praksa“ (januar/april 2005).

Ovaj časopis se, kao i većina američkih časopisa, sastoji od malog broja članaka i velikog broja prikaza. I jedna i druga komponenta daju izuzetno dobar pregled razvoja ove discipline $u$ anglosaksonskom govornom području. Stiče se, međutim, utisak da u ovom časopisu postoji određena nesrazmera u korist LBGTQ (lezbijskobiseksualnih-gej-transseksualnih-kvir) studija. Osim dva broja isključivo posvećena lezbijskim i gej istorijama, veliki je broj LBGTQ radova i u ostalim specijalnim brojevima.

${ }^{6}$ Allan M. Brandt, No Magic Bullet: A Social History of Venereal Disease in the United States Since 1880 (New York: Oxford University Press, 1987²); John D’Emilio and Estelle Freedman, Intimate Matters: A History of Sexu-ality in America (New York: Harper and Row, 1988); Lillian Faderman, Surpassing the Love of Men: Romantic Friendship and Love between Women from the Renaissance to the Present (New York: William Morrow, 1981); Idem, Odd Girls and Twilight Lovers: A History of Lesbian Life in Twentieth-Century America (New York: Columbia University Press, 1991); Johnatan Ned Katz, Gay American History (New York: Cromwell, 1976); Gay/Lesbian Almanac (New York: Harper and Row, 1983); James C. Mohr, Abortion in America: The Origins and Evolution of National Policy 1800 1900 (New York: Oxford University Press, 1978); David J. Pivar, Purity Crusade: Sexual Morality and Social Control 1868-1900 (Westport, CT: Greenwood Press, 1973); Elizabeth Pleck, Domestic Tyranny: The Making of American Social Policy against Family Violence from Colonial Times to the Present (New York: Oxford University Press, 1987); Kenneth Plummer, Sexual Stigma: An Interactionist Account (London: Routledge and Kegan Paul, 1975); Lee Rainwater, And the Poor Get Children: Sex, Contraception and Family Planning in the Working Class (Chicago: Quadrangle, 1975); Rosen Ruth, The Lost Sisterhood: Prostitution in America 1900-1918 (Baltimore: The Johns Hopkins University Press, 1982); Caroll Smith-Rosenberg, „The Female World of Love and Ritual“, Signs, I, № 1, (1975), 1-29; Ellen K. Rothman, Hands and Hearts: A History of Courtship in America (New York: Basic Books, 1984); Christine Stansell, City of Women: Sex and Class in New York 1789-1860 (New York: Alfred A. Knopf, 1986); Carole S. Vance, Pleasure and Danger: Exploring Female Sexuality (New York: Routledge and Kegan Paul, 1984); Jeffrey Weeks, Sex, Politics, and Society: The Regulation of Sexuality Since 1800 (London: Longman, 1981); Idem, Sexuality (London: Tavistock, 1986); Idem, Coming Out: Homosexual Politics in Britain from the Nineteenth Century to the Present (London: Quartet, 1977). Knjige su navedene prema dva rada: Стивен Сајдмен, „Социјални конструкционизам: социологија, историја и филозофија“, Теме, XXIII, бр. 1, (2009), 67-78. To je prevod trećeg poglavlja knjige: Steven Seidman, The Social Construction of Sexuality (New York: W. W. Norton \& Company, 2003). Drugi rad je: Estelle B. Freedman and John D'Emilio, „Problems Encountered in Writing the History of Sexuality: Sources, Theory and Interpretation“, The Journal of Sex Research, XXVII, № 4, (1990), 481-495. Ovo je samo deo knjiga koje navode ova dva rada. 
Nije lako pitanje kako izmeriti značaj istorije seksualnosti u širem okviru društvene istorije. Ovom prilikom ćemo se ograničiti na jednu studiju slučaja. Odabrali smo Enciklopediju evropske društvene istorije, koju je 2001. godine u šest tomova priredio Piter Sterns, kao neki opšti pregled tema iz društvene istorije. ${ }^{7}$ Piter Sterns je inače uređivao Journal of Social History od 1967. godine, a u tih četrdesetak godina napisao je i seriju knjiga - sinteza iz društvene istorije. ${ }^{8}$ Među njima za ovu temu je najvažnija knjiga Seksualnost u svetskoj istoriji, objavljena 2009. godine. ${ }^{9}$

Reč je, dakle, o vrlo velikom autoritetu i za društvenu istoriju uopšte, a i za istoriju seksualnosti. Kao što smo ranije rekli, enciklopedija ima šest tomova, a podeljena je na 23 tematske celine. Ova enciklopedija ukupno ima 207 odrednica, koje se mogu podeliti na one tematske celine u kojima je seksualnost sporedna tema i na one u kojima je većina odrednica, barem posredno, dotiče. Od tih 207 odrednica, seksualnošću se u užem ili širem smislu bavi 38 odrednica, što pokazuje da to više nikako nije marginalna tema društvene istorije.

Dodatno pitanje vezano za istoriju seksualnosti odnosi se na metodologiju i izvore. Slično kao i sa najbližom disciplinskom ,rođakom“, rodnom istorijom, skeptici su sumnjali u postojanje i količinu izvora za ovaj istorijski žanr. U početku su izvori bili medicinski dokumenti i razni zdravstveni priručnici. Već sredinom 1970ih uključeni su ženski dnevnici i pisma, ali i sudska dokumenta i novine. Sudska dokumenta i novine su doneli jednu opasnost za tumačenje. Po prirodi stvari, sudovi i crne hronike više prate odstupanja od norme i moralne prestupe nego li „,normalnu“ seksualnost. Pokazalo se da je sam pojam ,seksualnost“ sporan, jer su pre 20. veka umesto njega korišćeni drugi pojmovi. Recimo, reprodukcija, romansa, požuda, strast, itd. Taj problem je poznat i u drugim disciplinama, kao i pitanje predrasuda (naglasak na iskustvima srednje klase). Posebno važno pitanje istorije seksualnih identiteta vezano je za druge identitete: šta je ,prirodno“, a šta „,društveni konstrukt"? Time su se naročito bavili istoričari homoseksualnosti, ali i nekih drugih oblasti seksualnosti kao što su prostitucija i vanbračno rađanje dece. ${ }^{10}$

Kakvo je stanje razvoja ove discipline kod nas? Da bismo to saznali, trebalo bi da pratimo dva koloseka: prevođenje knjiga o istoriji seksualnosti i njihov uticaj, kao i nastajanje domaćih radova iz ove oblasti. U tekstu ćemo pominjati i radove koji se tiču seksualnosti iz srodnih disciplina, ukoliko su i ako su uticali na istoriografske radove. Najveći deo radova koje ćemo obrađivati seksualnošću se bave uzgred, najčešće uz neku temu iz rodne istorije. Teško je razdvojiti radove iz istorije seksualnosti od onih iz rodne istorije, pa i od onih iz porodične istorije. Zato će u ovom radu biti

${ }^{7}$ Peter N. Stearns, ed., Encyclopedia of European Social History from 1350 to 2000 (New York: Charles Scribner's Sons, 2001).

${ }^{8}$ Istaknimo samo neke: Peter N. Stearns, European Society in Upheaval: Social History since 1750 (New York: MacMillan Publishing Company, 1975); Idem, Gender in World History (London: Routledge, 2000); Idem, Consumerism in World History: The Global Transformation of Desire (London: Routledge, 2001); Idem, Childhood in World History (New York: Routledge, 2005); Idem, World History in Brief (New York: Pearson/Longman, 2007).

${ }^{9}$ Peter N. Stearns, Sexuality in World History (New York: Routledge, 2009).

${ }^{10}$ E. B. Freedman and J. D’Emilio, ,Problems Encountered in Writing the History of Sexuality“. 
reči i o delima iz tih isprepletanih oblasti. Mišljenja smo da u ovom pregledu ipak treba uzeti u obzir radove koji se makar koliko bave temom seksualnosti.

\section{Prevođenje knjiga iz istorije seksualnosti}

Dugo vremena su knjige iz istorije seksualnosti objavljivali izdavači koji se nisu bavili akademskom literaturom, ili u neakademskim edicijama (kao kada je reč o Prosveti). Tako je dvotomna Historija prostitucije izašla kod opskurnog izdavača. A možda najvažniju knjigu iz ove oblasti Istoriju seksualnosti Mišela Fukoa štampao je doduše ugledan izdavač Prosveta, ali u ediciji „Erotikon“ posvećenoj erotskoj književnosti. Veoma je upečatljiv podatak da su prva izdanja ovog velikog Fukoovog dela izašla iste 1978. godine u Beogradu i Njujorku. U vrlo prestižnoj ediciji ,Zenit““ početkom sledeće decenije objavljena je knjiga Reja Tanahila Čovek $i$ seks posvećena celokupnoj svetskoj istoriji seksualnosti.

Rano prevođenje nije imalo za posledicu preuzimanje ideja ni iz Fukoovog, niti drugih dela. Tako je i kultno delo Ladirija Montaju prevedeno srazmerno rano, a da nije proizvelo odjek na domaćoj akademskoj sceni. ${ }^{12}$ Tek će se krajem 20. i početkom 21. veka započeti sa sistematskim prevođenjem i uspostaviti veza između stranih knjiga i domaće produkcije. Za to su najzaslužnija dva izdavača: Geopoetika i Klio. Prvi pomenuti izdavač je još 1994. godine izdao knjigu oksfordskog profesora Teodora Zeldina Intimna istorija čovečanstva. U ovoj knjizi nekoliko poglavlja je posvećeno seksualnosti (,Kako su izmišljeni novi oblici ljubavi“, „Zašto se u kuvanju više napredovalo nego u seksu“, „Kako se želja koju muškarci osećaju prema ženama i prema drugim muškarcima menjala kroz vekove“). U 21. veku čitava edicija ovog izdavača „Intimna istorija“ sadrži niz knjiga posvećenih temama vezanim za seksualnost, dok se tema provlači i u pojedinim poglavljima drugih knjiga ove edicije. ${ }^{13}$

Ipak je izdavač kod koga se može naći najveći broj radova o seksualnosti Klio. Naravno, pre svega je reč o ediciji Istorija privatnog života. Od 2000. godine izašlo je pet tomova istorije privatnog života od antike do savremenog doba, zbornika radova koje su priredili najčuveniji francuski istoričari iz škole Anala. Ova istoriografska škola je od svih škola istoričarskog mišljenja možda najkompletnije i najdoslednije prevođena $\mathrm{i}$ kada su druge teme u pitanju. ${ }^{14}$ Prevođenje Istorija privatnog života sa

${ }^{11}$ Fernando Henrikes, Historija prostitucije, I-II (Zagreb: Epoha, 1968); Pavle Milenković, „Mišel Fuko: Bibliografija“, u: Mišel Fuko 1926-1984-2004. Hrestomatija, urednici Dušan Marinović i Pavle Milenković (Novi Sad: Vojvođanska sociološka asocijacija, 2005), 299-331; Rej Tanahil, Čovek $i$ seks (Beograd: Jugoslavija, 1981).

${ }^{12}$ Emanuel Le Roa Ladiri, Montaju, oksitansko selo od 1294. do 1324 (Sremski Karlovci/Novi Sad: Izdavačka knjižarnica Zorana Stojanovića, 1991).

${ }^{13}$ Džuli Enfild, Intimna istorija poljupca: jedan poljubac - hiljadu priča (Beograd: Geopoetika, 2007); Elizabet Abot, Istorija ljubavnica (Beograd: Geopoetika, 2006); Idem, Istorija celibata (Beograd: Geopoetika, 2008); Idem, Istorija braka: od istopolnih zajednica do ličnih zaveta i vanbračnih zajednica, iznenađujuća raznolikost jedne tradicije (Beograd: Geopoetika, 2014); Godfri Gudvin, Privatni svet osmanskih žena (Beograd: Geopoetika, 2015); Piter Englund, Male istorije (Beograd: Geopoetika, 2009).

${ }^{14}$ Predrag Marković, Miloš Ković, Nataša Milićević, „Developments in Serbian Historiography since 1989“, in: (Re)Writing History-Historiography in Southeast Europe after Socialism, editor Ulf Brunnbauer (Muenster: Lit Verlag, 2004), 277-316. 
francuskog nadahnuće nastanak projekta „Istorija privatnog života na tlu srpskih zemalja“, o čemu će biti reči na drugom mestu u ovom radu.

Ova edicija nije jedina u kojoj je Klio izdavao knjige koje se bave istorijom seksualnosti. Tu je i edicija Čovek u istoriji. U devet tomova posvećenih različitim epohama i zemljama (stari Egipat, antička Grčka, Rimsko carstvo, srednji vek, Vizantija, renesansa, barok, doba prosvećenosti, romantizam) opisani su svakodnevica, vrednosti i idejni svet ljudi. U skoro svakoj od ovih knjiga se nalazi poneko poglavlje vezano za seksualnost. Tu je i biblioteka Agora u kojoj se našom temom bave knjige Žena u istoriji Evrope, Istorija muškosti (retka istoriografska studija maskuliniteta), Emocije. Kratka istorija i Telo i društvo. ${ }^{15}$

Neposrednu saradnju sa istorijskim antropolozima koji se bave i temama seksualnosti uspostavilo je i Udruženje za društvenu istoriju. Ono je objavilo dve velike sinteze o rodnim odnosima: Kada je Adam kopao a Eva prela, oglede o prošlosti evropske porodice Mihaela Miterauera, kao i knjigu Karla Kazera Porodica i srodstvo na Balkanu: analiza jedne kulture koja nestaje. Ovo udruženje će započeti i dugogodišnju saradnju na zajedničkim istraživanjima sa univerzitetima u Gracu i Beču. ${ }^{16}$

Postoji veći broj pojedinačnih izdanja vezanih za istoriju seksualnosti, kao što su Seksualni stavovi Verna i Boni Buloh, knjiga Iv Levin o seksualnosti pravoslavnih Slovena u srednjem veku, Ljubav i Zapad Deni de Ružmona, ili Orgazam i Zapad Robera Mišambleda. ${ }^{17}$ Ipak, ovom prilikom smo se zadržali na knjigama koje su plod sistematske izdavačke politike, dakle koje su deo čitavih edicija (,kola“ kako bi rekli stari izdavači).

\section{Seksualnost - istoriografska tema o kojoj se nije govorilo?}

„O erotskom životu junaka se ne pripoveda. Erotska motivacija je implicitna, iščitava se kontekstualno““ ${ }^{18}$ Ovaj navod iz teksta Dragane Vukićević o erotskom diskursu u srpskoj prozi 19. veka naveo me je da se zapitam nije li i u istoriografiji seksualnost tema o kojoj se dugo nije govorilo? Ako se i pominjala, uglavnom je reč o negativnim pojavama. Vuk Karadžić, na primer, govori o seksualnom nasilju kao o jednom od uzroka početka bune na dahije: „Ne samo što su ji daije s njiovim kabadajiama i subašama do gole kože oglobile, nego im i $r z$ (obraz ili žensko poštenje) i

${ }^{15} \mathrm{http}: / /$ clio.rs/edicije.php (pristupljeno 1. 6. 2017); Gizela Bok, Žena u istoriji Evrope: od srednjeg veka do danas (Beograd: Clio, 2005); Volfgang Šmale, Istorija muškosti u Evropi 1450-2000 (Beograd: Clio, 2011); Kit Outli, Emocije. Kratka istorija (Beograd: Clio, 2005); Piter Braun, Telo i društvo: muškarci, žene i seksualno odricanje u ranom hrišćanstvu (Beograd: Clio, 2012).

${ }^{16}$ P. Marković, M. Ković, N. Milićević, op. cit.; Михаел Митерауер, Кад је Адам копао а Ева прела: историјско-антрополошки огледи из прошлости европске породице (Београд: Удружење за друштвену историју, 2001); Karl Kazer, Porodica i srodstvo na Balkanu: analiza jedne kulture koja nestaje (Beograd: Udruženje za društvenu istoriju, 2002).

${ }^{17}$ Vern L. Buloh i Boni Buloh, Seksualni stavovi (Beograd: Fabrika knjiga, 2004); Ив Левин, Сексуалност и друштво код православних Словена од X до XVIII века (Лозница: Карпос, 2006); Deni de Ružmon, Ljubav i Zapad (Beograd: Službeni glasnik, Karpos, 2011); Rober Mišambled, Orgazam i Zapad: istorija užitka od XVI veka do danas (Novi Sad: Akademska knjiga, 2016).

${ }^{18}$ Dragana Vukićević, ,Erotsko kriptogramsko pismo i patrijarhalni svet“", (rukopis predavanja). 
zakon pogaziše: muž nije gospodar od svoje žene, ni otac od kćeri, ni brat od sestre.“ Navedeni tekst je ušao u Vukovu ,zvaničnu“ Srpsku istoriju našega vremena. ${ }^{19}$ Jedan drugi Vukov opis, znatno slikovitiji, glasi: „Najposlije stanu silovati žene i đevojke: izgonili su ji u kolo, da igraju pred njiovim anovima i čardacima, ili pred čadorima, pa koje su im se dopadale, one su uzimale k sebi; tako danas jednu, a sjutra drugu: kašto po jednu, a kašto i po dvije i po tri u jedan put". Ovaj tekst je objavljen u manje poznatoj knjizi Građa za srpsku istoriju našega vremena. Tu je objavljena i priča o preokretu uloga nasilnika i žrtava, jer su tokom ustanka Srbi otimali Turkinje i pravili hareme, po čemu je najpoznatiji bio vojvoda Milenko Stojković, a priču o Milenkovom haremu ispisuje i Milan Đ. Milićević u svom Pomeniku znamenitih ljudi. Najsažetiji opis uloge seksualnog nasilja u ustanku dat je u još manje poznatim kazivanjima Gaje Pantelića. Karađorđe je prijatelju Gaji rekao pred ustanak da ne može više da gleda kako srpskim ženama vire noge ispod Turaka. Na kraju ustanka mu je kazao kako je srpsko nasilje nad turskim ženama dodatno razdražilo Turke. ${ }^{20}$

Posle Vuka, koji nije imao neke predrasude prema seksualnosti, kojom se uostalom bavio i kao sakupljač narodnih umotvorina, istoričari su dugo zaobilazili ovu temu. Paradigma takvog pristupa jeste Slobodan Jovanović, pisac najuticajnijih i najpopularnijih istoriografskih (publicističkih?) knjiga o 19. veku. Napisao je četiri toma o Milanu i Aleksandru Obrenoviću, na skoro 1.600 strana teksta. ${ }^{21}$ Koliko ima stranica o emotivnom životu ovih vladara čija su osećanja bila toliko burna da su dovodila do više kriza dinastije, a konačno i do nestanka loze? Ako isključimo 114 strana o svađama i razvodu kralja Milana i kraljice Natalije, kao i deo o ženidbi kralja Aleksandra i Drage Mašin, jer je priča o svađama, razvodu i ženidbi u velikoj meri prožeta političkim intrigama, Jovanović ima manje od 10 strana o emotivnom životu svojih junaka, uključujući i glasine o Milivoju Blaznavcu i Dragi Mašin. ${ }^{22}$ U pitanju verovatno nije autocenzura, već ubeđenje da postoje važne i nevažne istorijske činjenice. Ni emotivni život, a kamoli seksualnost, još nisu zaslužili status važne teme u njegovo vreme. Time je potvrđena teza Aleksandre Vuletić da su tokom 19. veka srpski intelektualci odbacivali temu ljubavi i emocija kao nedostojnu datog istorijskog trenutka. ${ }^{23}$

Pre devedesetih godina, rodna istorija je bila veoma slabo obrađivana, iako je za nju čak postojala zvanična politička inicijativa. Zanimljiv je podatak da je Antifašistički front žena (AFŽ) imao velike planove za rodnu istoriju. U februaru 1950. godine, Sekretarijat Centralnog odbora AFŽ-a doneo je odluku da se osnuje Komisija za prikupljanje istorijskog materijala za istoriju naprednog pokreta i uopšte aktivnosti žena Jugoslavije. Komisija, koju su sačinjavale najuglednije članice AFŽ-a, održala

${ }^{19}$ Вук Стефановић Караџић, Српска историја нашега времена (Београд: Нолит, 1969), 80.

${ }^{20}$ Navedeno prema: Драгана Антонијевић, „Насиље над женама и сексуални морал: потиснута повест устаничког доба у Србији“, Гласник Етнографског института САНУ, XLVII, (1998), $65-78$.

${ }^{21}$ Сабрана дела Слободана Јовановића, IV-VII (Београд: Београдски издавачко-графички завод, Југославијапублик, Српска књижевна задруга, 1990).

${ }^{22}$ Autor ovog teksta je inače skeptičan prema Jovanovićevom maniru pisanja bez navođenja izvora i literature. Ipak, činjenica da su i tako pisane njegove knjige i posle jednog veka bolje od većine drugih knjiga o tom vremenu, navodi na teško razmišljanje.

${ }^{23}$ Александра Вулетић, Брак у Кнежевини Србији (Београд: Завод за уџбенике, 2008), 289. 
je prvu sednicu već 30. marta i još najmanje dva sastanka u aprilu i maju te godine. Podeljene su hronološki razvrstane teme među članicama Komisije. Komisija je ustanovila kakvo je stanje građe i podelila istraživačke zadatke na 22 grupe, od položaja žena u predratnoj Jugoslaviji (podeljenih na društvene grupe), preko borbe žena za građanska prava, međunarodne saradnje do žena iz nacionalnih manjina. ${ }^{24}$ Nije poznato da li je ovaj koncept imao nekakve ishode u vidu tekstova o rodnoj istoriji, ne računajući nekoliko referata na partijskim i AFŽ skupovima.

Prva istoriografska akademska monografija koja je u celini posvećena ženama jeste doktorat Dušanke Dinić-Knežević odbranjen 1965. godine, pod naslovom „Položaj žena u Dubrovniku i Srbiji u 13. i 14. veku“, koji je objavljen sa kašnjenjem od 9 godina pod naslovom Položaj žena u Dubrovniku u 13. i 14. veku. Autorka je svesna svog prvenstva rekavši u uvodu „u našoj istoriografiji ženama je posvećeno malo pažnje ... ovaj rad u neku ruku predstavlja početak na tom polju istraživanja““. ${ }^{25}$ U ovoj knjizi već se koristi Žorž Dibi kao literatura, a dva poglavlja su u celosti posvećena braku i moralu.

\section{Šta su pisale druge nauke - najkraći osvrt}

Postoje mnogobrojni sociološki i antropološki radovi koji se bave seksualnošću, često u okviru proučavanja porodice i braka. Navešćemo samo neke од njih. Postoji i zanimljiva rodna razlika među istraživačima. Sada ćemo navesti samo dva karakteristična primera, koja ukazuju na glorifikaciju patrijarhalnog poretka koja se, izgleda, javlja kod muških istraživača. Sreten Vukosavljević je u svojim predavanjima i novinskim člancima tridesetih godina tvrdio da je položaj žena na selu „mnogo jači nego položaj buržoaske žene“, a da u zadruzi (sem položaja neveste) nije bio gori nego položaj muškaraca, iako u jednom od tih tekstova piše „da se na rađanje dece nije obraćala nikakva pažnja. Jedva onoliko koliko na mlaćenje stoke.“ Četrdeset godina kasnije, autor koji je doktorirao na položaju žena u prošlosti piše kako je poslušnost žena prema muškarcima bila potrebna i da to pokazuje svojevrsnu jednakost. Crnogorke su po ovom autoru, Vidaku Vujačiću, toliko volele svoje muževe da su im, ako nisu mogle imati dece, kao u Starom zavetu, nalazile drugu ženu i ponekad živele u bigamiji. ${ }^{26}$ Tema rodne pristrasnosti u istraživanju zaslužuje posebno istraživanje. Sada ćemo samo ustanoviti da su žene istraživači imale drugačiji stav. Za našu temu su najvažniji radovi sociološkinja Vere Erlih, Anđelke Milić i, u novije vreme, Smiljke Tomanović. Ova istraživanja su važna ne samo kao metodološki uzor, već posle nekoliko decenija i kao izvor. Recimo, Vera Erlih je izvršila terensko istraživanje ogromnih razmera u 300 sela Jugoslavije, od severa do

${ }^{24}$ Arhiv Jugoslavije (AJ), fond Antifašistički front žena (AFŽ), 141, fascikla 11, arhivska jedinica 57. Članice Komisije su bile Mila Čobanski, Beba Krajačić, Draga Stefanović, Krista Đorđević, Jelena Jančić, Marika Stojanović, Milica Dedijer i Nada Bogdanović.

${ }_{25}$ Душанка Динић-Кнежевић, Положај жена у Дубровнику у 13. и 14. веку (Београд: Српска академија наука и уметности, 1974), XVII.

${ }^{26}$ Сретен Вукосављевић, Историја сељачког друштва, V, Сеоске заједнице и облици понамања у њима (Београд: Службени гласник, 2012), 575-584; Видак Вујачић, Трансформација патријархалне породице у Црној Гори (Београд: Слово љубве, 1977), 68-77. 
juga. ${ }^{27}$ Danas njen rad nije samo nezaobilazno sociološko štivo, već je i redak i dragocen izvor za nekoliko istoriografskih disciplina (istorija porodice, istorija mentaliteta, pa i istorija seksualnosti). Podaci njenog istraživanja se ne mogu naći ni u jednom drugom izvoru. Anđelka Milić je osim mnogobrojnih radova o sociologiji porodice i žena, koji takođe mogu da posluže kao jedinstveni istorijski izvor, krajem osamdesetih godina napisala verovatno prvi rad o istoriji porodice. Što se sledeće generacije sociologa tiče, čiji je paradigmatični predstavnik Smiljka Tomanović, bez njihovih radova teško da ćemo moći da razumemo promene u istoriji porodice krajem 20. i početkom 21. veka. ${ }^{28}$ Nekoliko istoričarki mlađe generacije (i Momčilo Isić) iskoristilo je metod i nalaze navedenih sociološkinja. ${ }^{29}$ Neki naučnici su na vreme otvarali velike teme istorije seksualnosti, ali nemaju sledbenike, jer su im radovi objavljivani u inostranstvu. Takvi su iz ovog vremena izuzetno zanimljivi radovi Andreja Simića o stvaranju imidža muškosti i mačizmu i kriptomatrijarhartu u kulturi Južnih Slovena. ${ }^{30}$ Ovaj američki antropolog srpskog porekla ostaje redak primer izučavanja maskuliniteta, kod nas skoro potpuno zanemarene oblasti rodnih studija. Za utehu je podatak da su studije maskuliniteta zanemarene i u svetskoj istoriografiji. ${ }^{31}$ I u Srbiji je jedan od prvih radova o istorijatu ženskog pitanja nastao u redovima antropologa. To je rad Mirjane Prošić-Dvornić koji je izašao 1985. godine. I njena knjiga o odevanju sadrži elemente rodne istorije i istorije seksualnosti. ${ }^{32}$ Istoričari i teoretičari književnosti su još nedovoljno iskorišćeno nalazište metoda i znanja o istoriji seksualnosti. Naime, taj nevidljivi ledeni breg emotivnog života u prošlosti je ponekad moguće istražiti samo uz pomoć književnih dela. Već smo pominjali Draganu Vukićević, a tu su i Bojan T. Člak i Tatjana Rosić. ${ }^{33}$

${ }^{27}$ Vera Štajn-Erlih, Porodica u transformaciji: studija u tri stotine jugoslovenskih sela (Zagreb: Naprijed, 1964).

${ }_{28}$ Анђелка Милић, „Историја породице - изазов историји и социологији“, Зборник Филозофског факултета. Серија Б, Друштвене науке, XV, (1988), 359-372; Smiljka Tomanović, Odrastanje u Beogradu: oblikovanje socijalnih biografija mladih u porodicama dva društvena sloja (Beograd: Institut za sociološka istraživanja, 2010). Ne treba zanemariti ni zbornike radova: Društvene promene $i$ svakodnevni život: Srbija početkom devedesetih, urednik Silvano Bolčić (Beograd: Institut za sociološka istraživanja, 1995); i Društvena transformacija i strategije društvenih grupa: svakodnevica Srbije na početku trećeg milenijuma, urednik Anđelka Milić (Beograd: Institut za sociološka istraživanja, 2004).

${ }_{29}$ Aleksandra Vuletić, Ivana Dobrivojević, Momčilo Isić, Ivana Pantelić, Vera Gudac-Dodić, Ljubinka Škodrić i Nataša Milićević (videti napomenu 47).

${ }^{30}$ Andrei Simic, „Management of the Male Image in Yugoslavia“, Anthropological Quarterly, XLII, № 2, (1969), 89-101; Idem, „Machismo and Cryptomatriarchy: Power, Affect, and Authority in the Contemporary Yugoslav Family“", Ethos, XI, № 1/2, (1983), 66-86.

${ }^{31}$ Ivan Simić, „Global History and Gender Studies: Trends, Problems and Perspectives“, Годuшњак за друштвену историју, XVIII, br. 3, (2011), 103-113.

32 Мирјана Прошић-Дворнић, „Женско питање у Србији крајем 19. и почетком 20. века и часопис Домаћица 1879-1914“, Гласник Етнографског института САНУ, XXXIV, (1985), 47-70; Иста, „Одевање у Београду од 1878. до 1915. године“ (докторска дисертација, Универзитет у Београду, Филозофски факултет, 1984).

${ }_{33}$ Dragana Vukićević, „Kako reći i izbeći - erotska književnost u srpskoj nauci o književnosti“, u: Riječki filološki dani, uredila Estela Banov, (Rijeka: Filozofski fakultet, 2014), 261-270; Иста, „Интимни свет у мемоарској прози 18. века“, у: Наука и традиција, уредник Владимир Милисављевић (Пале: Филозофски факултет, 2013), 347-358; Бојан Т. Чолак, Модели представљања патријархалног друштва у прози српске модерне (докторска дисертација, Универзитет у Београду, Филолошки факултет, 2013); Татјана Росић, (Анти)утопије тела: репрезентаиија маскулинитета у савременој српској прози (Београд: Институт за књижевност и уметност, 2014). 
U istoriografiji sa velikom izvesnošću možemo kazati da su rodne studije, a u okviru njih studije seksualnosti procvetale devedesetih godina.

\section{Nastanak istorije seksualnosti kao discipline}

Kao što je rečeno ranije, istoriografija o seksualnosti je povezana sa rodnom istorijom. Iz današnje perspektive skoro neverovatno zvuči ocena Anđelke Milić da je prva sinteza iz rodne istorije izašla 1996. godine i to je knjiga Nede Božinović, koja čak nije ni istoričarka po vokaciji. Profesorka Milić smatra da knjiga Jovanke Kecman nije prava sinteza jer obuhvata užu temu i kraći vremenski raspon. Iste 1996. godine, Dunja Rihtman-Auguštin je priredila knjigu Lidije Sklevicki koja se bavila AFŽ-om u Hrvatskoj. Radoš Ljušić je u predgovoru svoje knjige Ljubavi srpskih vladara i političara istakao kako su „studije o ženskom pitanju kod nas u povoju“. On pominje samo jedan zbornik radova, upravo onaj u kome je izašao rad Anđelke Milić.

Ovo je još jedan pokazatelj koliko je pogrešna tvrdnja kako je srpska istoriografija stagnirala devedesetih godina. Mi smo u jednom ranijem radu pokazali da je stvarno stanje stvari bilo potpuno suprotno: devedesete godine su zbog velikog broja međunarodnih stipendista i međunarodnih projekata dovele do metodoloških novina u svim granama istoriografije, pa i rodnoj istoriji. ${ }^{34} \mathrm{U} 21$. veku i rodna istorija je, poput drugih istoriografskih oblasti, posebno onih iz društvene istorije, dalje rasla $i$ napredovala. Dvadesetak godina posle prvih knjiga iz rodne istorije, stanje je znatno bolje. Potvrđena je i tvrdnja iz jednog zbornika o rodnim odnosima u Jugoistočnoj Evropi, po kojoj su rodne studije jedna od najbrže rastućih oblasti u naukama koje se bave kulturom i društvom. ${ }^{35}$ Taj razvoj je, uz određeno zakašnjenje, obuhvatio i region Jugoistočne Evrope.

Početkom devedesetih godina radovi o seksualnosti su još uvek retki. U prvoj polovini devedesetih, ovom temom se bavi autor ovog rada. U svojoj knjizi o evropskim uticajima na proces modernizacije ovaj autor na nekoliko strana otvara pitanja vezana za stavove međuratnog društva o braku, seksualnosti, prostituciji i abortusu. U svojoj narednoj knjizi o beogradskom društvu u vreme Hladnog rata, isti autor se više bavi seksualnošću u medijima i masovnoj kulturi pedesetih i šezdesetih godina. ${ }^{36}$

${ }^{34}$ Anđelka Milić, ,Patrijarhalni poredak, revolucija i položaj žene“, u: Srbija u modernizacijskim procesima 19. i 20. veka, II, Položaj žene kao merilo modernizacije, urednica Latinka Perović (Beograd: Institut za noviju istoriju Srbije, 1998), 551-560. Reč je o knjigama: Neda Božinović, Žensko pitanje u Srbiji u 19. i 20. veku (Beograd: Devedesetčetvrta, Žene u crnom, 1996); Jovanka Kecman, Žene Jugoslavije u radničkom pokretu i ženskim organizacijama 1914-1941 (Beograd: Institut za savremenu istoriju, 1978); Lydia Sklevicky, Konji, žene, ratovi (Zagreb: Ženska infoteka, 1996); Радош Љушић, Љубави српских владара и политичара (Београд: Народна књига, 2001); P. Marković, M. Ković, N. Milićević, op. cit.

${ }^{35}$ „Introductory remarks“, Gender Relations in South Eastern Europe. Historical Perspectives on Womenhood and Manhood in 19th and 20th Century, Editors Miroslav Jovanović and Slobodan Naumović (Belgrade/Graz: Udruženje za društvenu istoriju, Institut für Geschichte der Universität, Arbteilung Südosteuropäische Geschichte, 2002), 7.

${ }^{36}$ Predrag Marković, Beograd i Evropa 1918-1941: evropski uticaji na proces modernizacija Beograda (Beograd: Savremena administracija, 1992); Isti, Beograd između Istoka i Zapada 1948-1965 (Beograd: Službeni list SRJ, 1996). 
Veliki prodor u izučavanju seksualnosti nastaće osnivanjem Udruženja za društvenu istoriju i njegovom saradnjom sa istoričarima i istorijskim antropolozima sa Univerziteta u Gracu (i nekolicinom iz Beča). Udruženje za društvenu istoriju je nastalo kao neformalna grupa studenata, postdiplomaca, doktoranada i mladih naučnika koji su uglavnom bili učenici Andreja Mitrovića, pod nazivom „Okrugli sto“. Okrugli sto je 1994. godine pokrenuo Godišnjak za društvenu istoriju, koji će tokom više od dve decenije izlaženja objaviti više radova o rodnoj i porodičnoj istoriji, pa i o seksualnosti. Od 1998. godine, ova neformalna družina je prerasla u Udruženje za društvenu istoriju. ${ }^{37}$ Krajem 1996. u Beogradu je u organizaciji Okruglog stola održana konferencija o istorijskoj antropologiji, čiji je plod bio zbornik objavljen 1999. godine. Na samom kraju 20. veka (2000. godine) održane su još dve konferencije od kojih je jedna posvećena detinjstvu, a druga rodnim odnosima u Jugoistočnoj Evropi tokom 19. i 20. veka (već smo naveli zbornik nastao sa konferencije o rodnim odnosima). ${ }^{38}$

Što se tiče rodnih studija, studija porodica i istorije emocija, u Godišnjaku je izašao veći broj radova, u proseku svake godine po jedan (ukupno 23). Kao što je rečeno, postoji dilema oko toga koji radovi iz rodne istorije i istorije porodice treba da se ubrajaju u istoriografiju o seksualnosti. Kao, na primer, dva rada Mileta Bjelajca o ženidbenoj strategiji srpskih oficira. ${ }^{39}$ Ukupno se naređalo 9 radova o seksualnosti, više od trećine od sva 23 rada na rodne i porodične teme. Prvi članak o seksualnosti u užem smislu objavljen u Godišnjaku za društvenu istoriju jeste temeljni tekst Vladimira Jovanovića o prostituciji u Beogradu tokom 19. veka. Sledeći tekst o ovoj temi jeste rad Svetlane Stefanović o pisanju lista Ženski pokret na sve važne teme seksualnosti, kao što su brak, slobodna ljubav, seksualno vaspitanje, kontracepcija i prostitucija. Krajem 20. veka, Vladimir Krivošejev napisao je zanimljivu studiju slučaja o jednom kupleraju u Valjevu. Od početka 21. veka, tematski i hronološki opseg radova objavljenih u Godišnjaku veoma je širok. Proteže se od Timotijevićevog rada o rađanju moderne emotivnosti, pa i one među supružnicima, preko Mihaila Grueva o homoseksualizmu u socijalističkoj Bugarskoj, pa rada Vlade Stankovića o vizantijskoj satiri na temu braka iz 12. veka, nakon koga dolazi Jankovićev rad o beogradskoj prostituciji u 19 . veku (redosled pominjanja je po godini objavljivanja). ${ }^{40}$ Posto-

${ }^{37} \mathrm{http} / / /$ www.udi.rs/about.asp (pristupljeno 1. 6. 2017).

${ }^{38}$ Between the Archives and the Field: a Dialogue on historical anthropology of the Balkans, editors Miroslav Jovanović, Karl Kaser and Slobodan Naumović (Belgrade/Graz: Udruženje za društvenu istoriju, Institut für Geschichte der Universität, Abteilung Südosteuropäische Geschichte, 1999).

${ }^{39}$ Миле Бјелајац, „Женидбе официра српске и југословенске војске 1881-1941. Планирано стварање елите“, Годишњак за друштвену историју, II, бр. 1, (1995), 19-38; Исти, „Женидбе српских официра до 1881. (Слика на пресеку 1874. године)“, Годишњак за друштвену историју, IV, бр. 1, (1997), 43-47.

${ }^{40}$ Владимир Јовановић, „Проституција у Београду током XIX века“, Годишњак за друштвену историју, IV, бр. 1, (1997), 7-24; Светлана Стефановић, „Женски покрет о проблему брака, слободне љубави, сексуалног васпитања, проституције и контроле рађања“, Годишњак за друштвену историју, V, бр. 1-3, (1998), 66-84; Владимир Кривошејев, „Крађа у Радњи за обављање проститутске делатности: један судски спор у Ваљеву 1895. године“, Годишњак за друштвену историју, VI, бр. 1, (1999), 67-75; Мирослав Тимотијевић, „Васпитање емоција и уобличавање модерног грађанског идентитета код Срба“, Годишњак за друштвену историју, XII, бр. 1-3, (2005), 7-24; Михаил Груев, „Комунизам и хомосексуализам у Бугарској 1944-1989“, Годишњак 
je i radovi sa perspektivom širom od regionalne. To je rad Alekseja Timofejeva o začetniku studija seksualnosti u Rusiji, Igoru Konu. Ivan Simić razmatra vezu globalne istorije i istorije roda. ${ }^{41}$

Do kraja 20. veka o rodnoj istoriji (donekle i o seksualnosti) izašla su dva zbornika radova, dve monografije i odbranjene su magistarske teze (u to vreme magistrature su bile otprilike kao današnji bolonjski doktorati). Prvi zbornik je Srbija u modernizacijskim procesima 19. i 20. veka, položaj žene kao merilo modernizacije, koji je 1998. godine priredila Latinka Perović. Od 46 radova, seksualnost, u najširem mogućem značenju dotiče 9 radova i to: dva rada o pravnom položaju žene, jedan rad o stavu pravoslavne crkve prema ženama, jedan rad o seoskoj ženi, dva rada o ženama u ravnogorskoj propagandi i praksi, dva rada o medijskom tretmanu žena u istoriji i jedan rad o desničarskim viđenjima žene. ${ }^{42}$ Drugi je pomenuti zbornik Between the Archives and the Field, o istorijskoj antropologiji koji je UDI izdalo 1999. godine, u kojem je od 17 radova pet posvećeno seksualnosti, braku i porodici. To su radovi Predraga Šarčevića o tobelijama, Zigfrida Grubera o razvoju strukture porodice i domaćinstva u Srbiji na primeru Orašca, Zorice Ivanović o zabrani braka među srodnicima u tradicionalnoj srpskoj kulturi, Predraga Markovića o seksualnosti u Beogradu i Miroslava Jovanovića o porodičnom i bračnom životu ruskih izbeglica. Već smo pomenuli skup o rodnim odnosima u Jugoistočnoj Evropi održan 2000. godine. Kasnije je izašao zbornik sa tog skupa u kojem ima 20 radova posvećenih raznim vidovima rodnih odnosa, od kojih su 9 pretežno istoriografski (njihovi autori su Krasimira Daskalova, Andrej Studen, Ana Stolić, Radina Vučetić, Kristina Popova, Violeta Ačkoska, Andrea Pete, Jasna Bakšić Muftić, Mihael Miterauer), a 4 antropološka rada imaju određenu istorijsku perspektivu (Ljupčo Risteski, Aneta Svetlieva, Predrag Šarčević, Petar Vodeničarov). Posebna pogodnost ovog zbornika je u tome što sadrži spisak i opis rada organizacija koje se bave ženskim studijama i opsežnu bibliografiju iz ove oblasti. ${ }^{43}$

Pionirska sinteza iz rodne istorije, knjiga Nede Božinović, bavila se uglavnom ženskim organizacijama i njihovim političkim i društvenim delovanjem. Neka vrsta monografije je knjiga Radoša Ljušića Ljubavi srpskih vladara i političara, koja je u prvom izdanju objavljena 2000 . godine. ${ }^{44}$ Ova knjiga je puna pikantnih detalja, a Ljušić u njoj katkad pominje i izvore i literaturu. O metodološkim ili teoretskim

за друштвену историју, XVII, бр. 3, (2010), 7-23; Влада Станковић, „Питање укуса и морала у византијском друштву 12. века: сатирични приказ мушко-женских односа у песми Теодора Продрома и њено значење“, Годишњак за друштвену историју, XVIII, бр. 2, (2011), 7-19; Иван Јанковић, „Обште блуднице: проституција у Београду у првој половини 19. века“, Годишњак за друштвену историју, XXII, бр. 2, (2015), 25-51.

${ }^{41}$ Алексеј Тимофејев, „Јагода на брези. Сексуална култура у Русији“, Годишњак за друштвену историју, XIX, бр. 3, (2012), 141-145; I. Simić, op. cit.

${ }^{42}$ Srbija u modernizacijskim procesima 19. i 20. veka. Položaj žene kao merilo modernizacije, urednica Latinka Perović (Beograd: Institut za noviju istoriju Srbije, 1998). Autori pomenutih radova su Olga Popović-Obradović, Marija Draškić, Vesna Nikolić-Ristanović, Radmila Radić, Momčilo Isić, Mihailo Stanišić, Bojan B. Dimitrijević, Predrag J. Marković, Svetlana Stefanović i Branko Nadoveza.

${ }^{43}$ Videti gore: Between the Archives and the Field. 2000).

${ }^{44}$ N. Božinović, n. d.; Радош Љушић, Љубави српских владара и политичара (Ниш: Зограф, 
vidovima ove teme nema ni govora. Dva najobimnija rada iz rodne istorije do 2000. godine su pomenute dve magistarske teze. Prva je magistarska teza Ane Stolić, odbranjena 1996. godine, štampana kao knjiga u više izdanja. Ova knjiga Ane Stolić je dekonstruisala jedan od najupornijih mizoginih mitova naše istorijske svesti, a to je mit o nemoralu Drage Mašin. Autorka u svojoj knjizi, posebno u njenom poslednjem izdanju, obilato koristi teorijska iskustva drugih nauka. Druga magistratura o kojoj je reč je ona Svetlane Stefanović, o ženskom pitanju u beogradskoj štampi i periodici, koja na žalost čitalaca nije objavljena kao knjiga, već je iz nje proisteklo nekoliko radova. Čitavo poglavlje magistrature Svetlane Stefanović, skoro četvrtina rada, pod naslovom „Žena i muškarac“, posvećeno je seksualnim temama: braku, prostituciji, seksualnom vaspitanju i pobačaju. Niko pre ni posle nje nije dao tako temeljnu analizu odnosa javnog mnjenja, tada predstavljenog kroz periodiku, prema seksualnosti. ${ }^{45}$

\section{Nagli razvoj istorije seksualnosti u 21. veku}

Prelom vekova doneo je velike promene u istoriografiji o seksualnosti, kao i u sve one grane istorijske nauke privlačne za međunarodnu saradnju. Za to postoji nekoliko razloga. Prekinuta je skoro decenijska izolacija akademske zajednice. Saradnja sa svetom je postojala i devedesetih, ali je bila proizvod ili lične inicijative ili stranih donacija. Sada su država i druge institucije preuzele brigu o međunarodnoj saradnji, što se videlo u podršci izdavačima i strukturi naučnih projekata. Bar je nekoliko projekata na Beogradskom i Novosadskom univerzitetu bilo posvećeno ženskim studijama. A početkom 21. veka još nisu presušile ni strane donacije. Dobar primer saradnje naučnika, izdavača i društvene zajednice jeste projekat izdavačke kuće Klio „Privatni život Srba“ koji je obuhvatio vreme od srednjeg do 20. veka. Pod rukovođenjem stručne redakcije, napravljeno je pet zbornika i jedna sinteza. ${ }^{46} \mathrm{U}$ svakom od tih zbornika je bar po jedno poglavlje posvećeno seksualnosti. Neka od tih poglavlja su prerasla u posebne knjige.

U 21. veku je nikla čitava biblioteka mahom iz pera istoričarki koje su se bavile rodnom istorijom (i istorijom porodice). Pomenimo ih po azbučnom redu prezimena, a navešćemo i broj knjiga iz rodne istorije svake autorke/autora. Priređene knjige i manje radove nismo brojali: Jelena Batinić (doktorska disertacija); Anđelka Bulatović (1); Sarita Vujković (1); Aleksandra Vuletić (3); Radina Vučetić-Mladenović (1); Vera Gudac-Dodić (1 i jedna zajednička); Momčilo Isić (jedna knjiga i zajednička

45 Ана Столић, Краљииа Драга (Београд: Завод за уџбенике, 2009); Svetlana Stefanović, „Žensko pitanje u beogradskoj štampi i periodici 1918-1941“ (magistarski rad, Univerzitet u Beogradu, Filozofski fakultet, 2000).

${ }^{46}$ Приватни живот у српским земљама средњег века, приредиле Смиља МарјановићДушанић и Даница Поповић (Београд: Clio, 2004); Приватни живот Срба у освит модерног доба, приредио Александар Фотић (Београд: Clio, 2005); Рађање модерне приватности, приредио Мирослав Тимотијевић (Београд: Clio, 2006); Приватни живот код Срба у 19. веку, приредили Ана Столић и Ненад Макуљевић (Београд: Clio, 2006); Приватни живот код Срба у 20. веку, приредио Милан Ристовић (Београд: Clio, 2007); i sinteza: Марко Поповић, Мирослав Тимотијевић и Милан Ристовић, Историја приватног живота у Срба: од средњег века до савременог доба (Београд: Clio, 2011). 
knjiga sa Verom Gudac-Dodić); Ivan Janković (1); Jasmina Milanović (1); Božica Mladenović (3); Ivana Pantelić (1 samostalna, jedna zajednička i doktorska disertacija); Ivana B. Spasović (4); Ana Stolić (2); Ljubinka Škodrić (doktorska disertacija i jedna zajednička knjiga). ${ }^{47} \mathrm{U}$ ovom radu bavićemo se knjigama iz rodne istorije samo onoliko koliko se one bave seksualnošću. Primećuje se da je tema skoro svih ovih knjiga istorija 19. i 20. veka. Hronološki su prve dve knjige Aleksandre Vuletić o porodici i braku u Srbiji 19. veka. Obe ove studije su pokazne vežbe kako se konkretnim istraživanjima izvora razbijaju predrasude. Kada je u pitanju rodna istorija, jedan od glavnih stereotipa vezanih za naš narod jeste mišljenje o prevladavanju zadruge, koje se zadržalo sve do 21. veka (videti knjigu Karla Kazera). Taj stereotip imao je za posledicu egzotizovanje čitave naše kulture koja se tobože, već i po zadružnoj porodičnoj strukturi, tako razlikovala od inokosne porodične strukture većine evropskih zemalja. Vuletićka je međutim dokazala da je u Srbiji već sredinom 19. veka prevladavala inokosna porodica. Knjiga o braku (jedna od retkih naših knjiga opremljena predmetnim indeksom), kao malo knjiga pre nje koristi obilatu sociološku i antropološku literaturu, kao i strane knjige o istoriji porodice i roda. Zanimljive su njene teze o ulozi nacionalne ideologije u shvatanju braka. ${ }^{48}$ Sasvim osobena knjiga iz istorije seksualnosti jeste Kata Nesiba, pravnika i sociologa Ivana Jankovića.

${ }^{47}$ Jelena Batinić, Gender, Revolution, and War: The Mobilization of Women in the Yugoslav Partisan Resistance During World War II (San Francisco: Stanford University, 2009); Анђелка Булатовић, Црногорка у XX вијеку (Београд: Задужбина Адрејевић, 2011); Сарита Вујковић, У граћанском оделу. Идентитети жена босанскохериеговачке грађанске културе 1878-1941 (Београд/Бања Лука: Културни центар Београда, Музеј савремене умјетности Републике Српске, 2010); Александра Вулетић, Породица у Србији средином 19. века (Београд: Историјски институт, Службени гласник, 2003); Иста, Брак у Кнежевини Србији (Београд: Завод за уџбенике, 2008); Александра Вулетић и Јасна Мијаиловић, Између посела и балова. Живот у Србији у 19. веку (Београд: Завод за уџбенике, 2005); Радина Вучетић-Младеновић, Европа на Калемегдану. „Цвијета Зузорић“ и културни живот Београда 1918-1941 (Београд: Институт за новију историју Србије, 2003); Вера Гудац-Додић, Жена у соиијализму. Положај жена у Србији у другој половини 20. века (Београд: Институт за новију историју Србије, 2006); Вера Гудац-Додић, Момчило Исић, Жена је темељ куће: жена и породица у Србији током двадесетог века (Београд, Институт за новију историју Србије, 2011); Momčilo Isić, Seljanka u Srbiji u prvoj polovini 20. veka (Beograd: Helsinški odbor za ljudska prava, 2008); Иван Јанковић, Ката Несиба и коментари (Београд: Фабрика књига, 2017); Јасмина Милановић, Делфа Иванић: заборављене успомене (Београд: Еволута, 2015); Божица Младеновић, Жена у Топличком устанку 1917 (Београд: Социјална мисао, 1996); Иста, Породица у Србији у Првом светском рату (Београд: Историјски институт, 2006); Иста, Судбина жене у pamy: Роса Пантић (1891-1945) (Београд: Историјски институт, 2012); Ivana Pantelić, Partizanke kao građanke: društvena emancipacija partizanki u Srbiji 1945-1953 (Beograd: Institut za savremenu istoriju, Evoluta, 2011); Ивана Пантелић, Јелена Милинковић и Љубинка Шкодрић, Двадесет жена које су обележиле ХХ век у Србији, I-II (Београд: НИН, 2013); Ivana Pantelić, „Jovanka Broz i srpska javnost 1952-2013“ (doktorska disertacija, Univerzitet u Beogradu, Filozofski fakultet, Odeljenje za istoriju, 2016); Ивана Б. Спасовић, Злата вредне: образовање женске деце у Јужном Банату од 1874. до 1918. године (Панчево: Историјски архив, 2014); Иста, Четврти сталеж: жена кроз историју. Прилози (Вршац: Висока школа струковних студија за васпитаче Михаило Палов, 2014); Иста, Кнегиње и краљиие династије Обреновић (Чачак: Пчелица, 2016); Иста, Кнегиње и краљище династије Карађорђевић (Чачак: Пчелица, 2016); Ана Столић, Сестре Српкиње: појава покрета за еманщипаџију жена и феминизма у Краљевини Србији (Београд: Еволута, 2015); Љубинка Шкодрић, Положај жене у окупираној Србији 1941-1944 (докторска дисертација, Универзитет у Београду, Филозофски факултет, Одељење за историју, 2015).

${ }^{48}$ А. Вулетић, Породииа у Србији средином 19. века; Иста, Брак у Кнежевини Србији. 
Pisana neobičnim literarnim stilom, ova knjiga je jedna od najzanimljivijih studija slučaja u našoj istoriografiji, koja kroz sudbinu jedne „bludnice“ daje čitavu sliku „bluda u Beogradu“"kako kaže autor. ${ }^{49}$

Kraj 19. i početak 20. veka nisu dovoljno obrađeni iz ugla naše teme. Postoji nekoliko knjiga rodne istorije koje obrađuju ovo razdoblje, ali se uglavnom bave drugim vidovima ženskog života. Momčio Isić će u svojoj studiji o seljanki u prvoj polovini 20. veka dotaći i temu seksualnosti. ${ }^{50} \mathrm{Za}$ razliku od ranijih knjiga koje se bave seoskim društvom, Isić daje temporalnu dimenziju i pokazuje dinamiku društvenih promena na selu, pa tako i u sferi rodnih odnosa i seksualnosti.

Seksualnost u Drugom svetskom ratu obrađuju čak tri studije: Jelene Batinić, Ivane Pantelić i Ljubinke Škodrić. Jelena Batinić pokazuje kako je seksualnost postala političko pitanje. Neprijatelji partizanskog pokreta su optuživali partizane za razvrat i sve moguće seksualne izopačenosti. Partizani su za razliku od svojih protivnika regrutovali mnogo žena, što ih je činilo lakom metom za ovakvu propagandu. Zvanična istoriografija a i sećanja učesnika NOP-a su, s druge strane, isticali „visoke moralne standarde". Njihov zvaničan moralni kod je bio asketizam uz izuzetke (koji su uključivali i samog Tita). Partija je strogo motrila na moralne karakteristike drugova, a pre svega drugarica. Ivana Pantelić opisuje slučaj kada su partizanku streljali zbog intimnih odnosa (naravno, ne i njenog partnera). Najširu sliku ženske seksualnosti u ratu daje Ljubinka Škodrić, koja je seksualnosti posvetila nekoliko poglavlja svog doktorata. Ona je obuhvatila širok spektar života žena u ratu: od onih pod okupacijom, do onih u ravnogorskom i partizanskom pokretu, kao i razne aspekte od „horizontalne kolaboracije“ preko raznih vidova strategija preživljavanja do propagandnih slika i aktivne borbe. ${ }^{51}$

Seksualnim životom žena u socijalizmu bavila se Vera Gudac-Dodić u dve svoje knjige, najviše problemima braka i razvoda i problemima zdravstvene zaštite, posebno abortusa. Od manjih radova o seksualnosti posebno se ističe rad Ivane Dobrivojević o planiranu porodice u socijalističkoj Jugoslaviji. ${ }^{52}$

U 21. veku, posebno u njegovoj drugoj deceniji, došlo je do pojave studija koje se bave LBTQ istorijskim temama. Postoji časopis $Q T$ za kvir teoriju i kulturu, koji je veći deo jedne sveske posvetio istoriji. Prvih stotinak strana zbornika Među nama su posvećeni lezbijskoj i gej istoriji od srednjeg veka do Drugog svetskog rata. ${ }^{53}$ Zanimljiva je činjenica da postoji časopis za kvir studije, ali ne i časopis za studije seksualnosti uopšte. Isto tako, ne postoje zbornici kojima je jedina tema sek-

${ }^{49}$ И. Јанковић, Ката Несиба и коментари.

${ }^{50}$ M. Isić, Seljanka u Srbiji u prvoj polovini 20. veka.

51 J. Batinić, op. cit., 219-280; I. Pantelić, Partizanke kao građanke, 67-68; Љ. Шкодрић, „Интимне везе са окупатором“, „Љубав, брак и породични односи“, „Жена у равногорској идеологији и пропаганди“, „Официр и жена“, „Идеолошки противници и партизанке“, „Партизанске љубави“, у: Положај жене у окупираној Србији 1941-1944, 79-97, 197-215, 233-247, 264-278, $354-383$.

${ }^{52}$ В. Гудац-Додић, Жена у соиијализму, 81-114, 133-156; Иста, Жена је темељ куће, 127145; Ivana Dobrivojević, „Planiranje porodice u Jugoslaviji 1945-1974“, Istorija 20. veka, XXXIV, br. 2, (2016), 83-98.

${ }_{53}$ „Uvod u teoriju prestupa“, $Q T$, I, br. 3-4, (2010); Među nama: neispričane priče gej i lezbijskih života, uredile Jelisaveta Blagojević i Olga Dimitrijević (Beograd: Hartefakt Fond, 2014). 
sualnost uopšte. Kao što smo videli, celokupno izučavanje seksualnosti izvan LBGTQ studija sprovodilo se kao deo širih istraživanja istorije roda i porodice. Kao i u SAD i u Zapadnoj Evropi, naučnici koji se bave LGBTQ studijama organizovali su svoja izučavanja u izdvojene studije tih identiteta.

\section{Šta da se radi?}

Iz svega navedenog proizlazi nekoliko mogućih zadataka. Prvo, potrebno je stvoriti makar jednu sintezu iz istorije seksualnosti. Kao što smo videli, postoje poglavlja monografija, postoji veliki broj manjih radova. Došlo je vreme za objedinjavanje svega toga u jednu preglednu celinu. Drugo, da bi se stvorila ta sinteza, potrebno je koristiti dostignuća raznih nauka. Ne samo sociologije i antropologije, već i istorije i teorije književnosti, kao i teorije popularne kulture i medija. Nikako ne treba zaobići ni razne medicinske i demografske studije, od onih koje su u prvoj polovini 20. veka pisali Milan Jovanović Batut i Aleksandar Petrović, do onih koje su u 21. veku pisale Mirjana Rašević i Katarina Sedlecki. A pri svemu tome, sačuvati osećaj za opštiji kontekst, koji bi obuhvatio ne samo rodnu već i društvenu i kulturnu istoriju.

\section{IZVORI I LITERATURA}

- Arhiv Jugoslavije (AJ), Antifašistički front žena, 141.

- Караџић, Вук Стефановић. Српска историја намега времена. Београд: Нолит, 1969.

- Abot, Elizabet. Istorija ljubavnica. Beograd: Geopoetika, 2006.

- Abot, Elizabet. Istorija celibata. Beograd: Geopoetika, 2008.

- Abot, Elizabet. Istorija braka: od istopolnih zajednica do ličnih zaveta i vanbračnih zajednica, iznenađujuća raznolikost jedne tradicije. Beograd: Geopoetika, 2014.

- Антонијевић, Драгана. „Насиље над женама и сексуални морал: потиснута повест устаничког доба у Србији“. Гласник Етнографског института САНУ, XLVII, (1998), 65-78.

- Batinić, Jelena. Gender, Revolution, and War: The Mobilization of Women in the Yugoslav Partisan Resistance During World War II. San Francisco: Stanford University, 2009.

- Berk, Piter. Istorija i društvena teorija. Beograd: Equilibrium, 2002.

- Between the Archives and the Field: a Dialogue on historical anthropology of the Balkans. Editors Miroslav Jovanović, Karl Kaser and Slobodan Naumović. Belgrade/Graz: Udruženje za društvenu istoriju, Institut für Geschichte der Universität, Abteilung Südosteuropäische Geschichte, 1999.

- Бјелајац, Миле. „Женидбе официра српске и југословенске војске 1881-1941. Планирано стварање елите“, Годишњак за друштвену историју, II, br. 1, (1995), 19-38. 
- Бјелајац, Миле. „Женидбе српских официра до 1881. године (Слика на пресеку 1874. године), IV, br. 1, (1997), 43-47.

- Blek Džeremi, i Donald M. Makrejld. Izučavanje istorije. Beograd: Clio, 2007.

- Bok, Gizela. Žena u istoriji Evrope: od srednjeg veka do danas. Beograd: Clio, 2005.

- Božinović, Neda. Žensko pitanje u Srbiji u 19. i 20. veku. Beograd: Devedesetčetvrta, Žene u crnom, 1996.

- Brandt, Allan M. No Magic Bullet: A Social History of Venereal Disease in the United States since 1880. New York: Oxford University Press, 1987².

- Braun, Piter. Telo i društvo: muškarci, žene i seksualno odricanje u ranom hrišćanstvu. Beograd: Clio, 2012.

- Булатовић, Анђелка. Црногорка у XX вијеку. Београд: Задужбина Адрејевић, 2011.

- Buloh Vern L., i Boni Buloh, Seksualni stavovi. Beograd: Fabrika knjiga, 2004.

- Чолак, Бојан Т. Модели представљања патријархалног друштва у прози сриске модерне. Докторска дисертација, Универзитет у Београду, Филолошки факултет, 2013.

- D'Emilio John, and Estelle Freedman. Intimate Matters: A History of Sexuality in America. New York: Harper and Row, 1988.

- Динић-Кнежевић, Душанка. Положај жена у Дубровнику у 13. и 14. веку. Београд: Српска академија наука и уметности, 1974.

- Dobrivojević, Ivana. „Planiranje porodice u Jugoslaviji 1945-1974“, Istorija 20. veka, XXXIV, br. 2, (2016), 83-98.

- Društvena transformacija i strategije društvenih grupa: svakodnevica Srbije na početku trećeg milenijuma. Urednik Anđelka Milić. Beograd: Institut za sociološka istraživanja, 2004.

- Društvene promene i svakodnevni život: Srbija početkom devedesetih. Urednik Silvano Bolčić. Beograd: Institut za sociološka istraživanja, 1995.

- Enfild, Džuli. Intimna istorija poljupca: jedan poljubac - hiljadu priča. Beograd: Geopoetika, 2007.

- Englund, Piter. Male istorije. Beograd: Geopoetika, 2009.

- Freedman Estelle B., and John D'Emilio. „Problems Encountered in Writing the History of Sexuality: Sources, Theory and Interpretation", The Journal of Sex Research, XXVII, № 4, (1990), 481-495.

- Faderman, Lillian. Surpassing the Love of Men: Romantic Friendship and Love between Women from the Renaissance to the Present. New York: William Morrow, 1981.

- Faderman, Lillian. Odd Girls and Twilight Lovers: A History of Lesbian Life in Twentieth-Century America. New York: Columbia University Press, 1991.

- Fout, John C. „A Note from the Editor“. Journal of the History of Sexuality, I, № 1, (1990), 1-2.

- Gay/Lesbian Almanac. New York: Harper and Row, 1983.

- Gender Relations in South Eastern Europe. Historical Perspectives on Womenhood and Manhood in 19th and 20th Century. Editors Miroslav Jovanović and Slobodan 
Naumović. Belgrade/Graz: Udruženje za društvenu istoriju, Institut für Geschichte der Universität, Arbteilung Südosteuropäische Geschichte, 2002.

- Груев, Михаил. „Комунизам и хомосексуализам у Бугарској 1944-1989“. Годишґак за друштвену историју, XVII, бр. 3, (2010), 7-23.

- Гудац-Додић, Вера. Жена у соиијализму. Положај жена у Србији у другој половини 20. века. Београд: Институт за новију историју Србије, 2006.

- Гудац-Додић Вера, и Момчило Исић. Жена је темељ куће: жена и породица у Србији током двадесетог века. Београд, Институт за новију историју Србије, 2011.

- Gudvin, Godfri. Privatni svet osmanskih žena. Beograd: Geopoetika, 2015.

- Henrikes, Fernando. Historija prostitucije, I-II. Zagreb: Epoha, 1968.

- Isić, Momčilo. Seljanka u Srbiji u prvoj polovini 20. veka. Beograd: Helsinški odbor za ljudska prava, 2008.

- Јанковић, Иван. „Обште блуднице: проституција у Београду у првој половини 19. века“. Годишъак за друштвену историју, XXII, бр. 2, (2015), 25-51.

- Јанковић, Иван. Ката Несиба и коментари. Београд: Фабрика књига, 2017.

- Јовановић, Владимир. „Проституција у Београду током XIX века“. Годишъак за друштвену историју, IV, бр. 1, (1997), 7-24.

- Katz, Johnatan Ned. Gay American History. New York: Cromwell, 1976.

- Kazer, Karl. Porodica i srodstvo na Balkanu: analiza jedne kulture koja nestaje. Beograd: Udruženje za društvenu istoriju, 2002.

- Kecman, Jovanka. Žene Jugoslavije u radničkom pokretu i ženskim organizacijama 1914-1941. Beograd: Institut za savremenu istoriju, 1978.

- Кривошејев, Владимир. „Крађа у Радњи за обављање проститутске делатности: један судски спор у Ваљеву 1895. године“. Годишъак за друштвену историју, VI, бр. 1, (1999), 67-75.

- Kuper Adam, i Džesika Kuper, prir. Enciklopedija društvenih nauka. Beograd: Službeni glasnik, 2009.

- Ladiri, Emanuel Le Roa. Montaju, oksitansko selo od 1294. do 1324. Sremski Karlovci/Novi Sad: Izdavačka knjižarnica Zorana Stojanovića, 1991.

- Левин, Ив. Сексуалност и друштво код православних Словена од X до XVIII века. Лозница: Карпос, 2006.

- Љушић, Радош. Љубави српских владара и политичара. Београд: Народна књига, 2001.

- Marković, Predrag. Beograd i Evropa 1918-1941: evropski uticaji na proces modernizacija Beograda. Beograd: Savremena administracija, 1992.

- Marković, Predrag. Beograd između Istoka i Zapada 1948-1965. Beograd: Službeni list SRJ, 1996.

- Marković Predrag, Ković Miloš and Nataša Milićević. „Developments in Serbian Historiography since 1989“. In: (Re)Writing History-Historiography in Southeast Europe after Socialism. Editor Ulf Brunnbauer, 277-316. Muenster: Lit Verlag, 2004.

- Među nama: neispričane priče gej i lezbijskih života. Uredile Jelisaveta Blagojević i Olga Dimitrijević. Beograd: Hartefakt Fond, 2014. 
- Милановић, Јасмина. Делфа Иванић: заборављене успомене. Београд: Еволута, 2015.

- Миленковић, Павле. Школа Анала. Огледи о социолошкој историографији. Нови Сад: Stylos, 2004.

- Milenković, Pavle. „Mišel Fuko: Bibliografija“. U: Mišel Fuko 1926-1984-2004. Hrestomatija. Urednici Dušan Marinović i Pavle Milenković, 299-331. Novi Sad: Vojvođanska sociološka asocijacija, 2005.

- Милић, Анђелка. „Историја породице - изазов историји и социологији“. Зборник Филозофског факултета. Серија Б, Друштвене науке, XV, (1988), 359-372.

- Milić, Anđelka. „Patrijarhalni poredak, revolucija i položaj žene“. U: Srbija u modernizacijskim procesima 19. i 20. veka, II, Položaj žene kao merilo modernizacije. Urednica Latinka Perović, 551-560. Beograd: Institut za noviju istoriju Srbije, 1998.

- Mišambled, Rober. Orgazam i Zapad: istorija užitka od XVI veka do danas. Novi Sad: Akademska knjiga, 2016.

- Митерауер, Михаел. Кад је Адам копао а Ева прела: историјскоантрополошки огледи из прошлости европске породице. Београд: Удружење за друштвену историју, 2001.

- Младеновић, Божица. Жена у Топличком устанку 1917. Београд: Социјална мисао, 1996.

- Младеновић, Божица. Породища у Србији у Првом светском рату. Београд: Историјски институт, 2006.

- Младеновић, Божица. Судбина жене у рату: Роса Пантић (1891-1945). Београд: Историјски институт, 2012.

- Mohr, James C. Abortion in America: The Origins and Evolution of National Policy 1800-1900. New York: Oxford University Press, 1978.

- Outli, Kit. Emocije. Kratka istorija. Beograd: Clio, 2005.

- Pantelić, Ivana. Partizanke kao građanke: društvena emancipacija partizanki u Srbiji 1945-1953. Beograd: Institut za savremenu istoriju, Evoluta, 2011.

- Пантелић Ивана, Милинковић Јелена и Љубинка Шкодрић, Двадесет жена које су обележиле ХХ век у Србији, I-II. Београд: НИН, 2013.

- Pantelić, Ivana. „Jovanka Broz i srpska javnost 1952-2013“. Doktorska disertacija, Univerzitet u Beogradu, Filozofski fakultet, Odeljenje za istoriju, 2016.

- Papić, Žarana. Polnost i kultura. Telo i znanje u socijalnoj antropologiji. Beograd: XX vek, 1997.

- Pivar, David J. Purity Crusade: Sexual Morality and Social Control 1868-1900. Westport, CT: Greenwood Press, 1973.

- Pleck, Elizabeth. Domestic Tyranny: The Making of American Social Policy against Family Violence from Colonial Times to the Present. New York: Oxford University Press, 1987.

- Plummer, Kenneth. Sexual Stigma: An Interactionist Account. London: Routledge and Kegan Paul, 1975. 
- Поповић Марко, Тимотијевић Мирослав и Милан Ристовић. Историја приватног живота у Срба: од средњег века до савременог доба. Београд: Clio, 2011.

- Приватни живот у српским земљама средњег века. Приредиле Смиља Марјановић-Душанић и Даница Поповић. Београд: Clio, 2004.

- Приватни жсиот Срба у освит модерног доба. Приредио Александар Фотић. Београд: Clio, 2005.

- Приватни живот код Срба у 19. веку. Приредили Ана Столић и Ненад Макуљевић. Београд: Clio, 2006.

- Приватни живот код Срба у 20. веку. Приредио Милан Ристовић. Београд: Clio, 2007.

- Прошић-Дворнић, Мирјана. „Одевање у Београду од 1878. до 1915. године“. Докторска дисертација, Универзитет у Београду, Филозофски факултет, 1984.

- Прошић-Дворнић, Мирјана. „Женско питање у Србији крајем 19. и почетком 20. века и часопис Домаћица 1879-1914“. Гласник Етнографског института CAHУ, XXXIV, (1985), 47-70.

- Рађање модерне приватности. Приредио Мирослав Тимотијевић. Београд: Clio, 2006.

- Rainwater, Lee. And the Poor Get Children: Sex, Contraception and Family Planning in the Working Class. Chicago: Quadrangle, 1975.

- Росић, Татјана. (Анти)утопије тела: репрезентација маскулинитета у савременој српској прози. Београд: Институт за књижевност и уметност, 2014.

- Rothman, Ellen K. Hands and Hearts: A History of Courtship in America. New York: Basic Books, 1984.

- Ruth, Rosen. The Lost Sisterhood: Prostitution in America 1900-1918. Baltimore: The Johns Hopkins University Press, 1982.

- Ružmon, Deni de. Ljubav i Zapad. Beograd: Službeni glasnik, Karpos, 2011.

- Сабрана дела Слободана Јовановића, IV-VII. Београд: Београдски издавачкографички завод, Југославијапублик, Српска књижевна задруга,1990.

- Сајдмен, Стивен. „Социјални конструкционизам: социологија, историја и филозофија“. Теме, XXIII, бр. 1, (2009), 67-78.

- Seidman, Steven. The Social Construction of Sexuality. New York: W. W. Norton \& Company, 2003.

- Simic, Andrei. „Management of the Male Image in Yugoslavia“. Anthropological Quarterly, XLII, № 2, (1969), 89-101.

- Simic, Andrei. „Machismo and Cryptomatriarchy: Power, Affect, and Authority in the Contemporary Yugoslav Family“. Ethos, XI, № 1/2, (1983), 66-86.

- Simić, Ivan. „Global History and Gender Studies: Trends, Problems and Perspectives“. Годишњак за друштвену историју, XVIII, br. 3, (2011), 103-113.

- Sklevicky, Lydia. Konji, žene, ratovi. Zagreb: Ženska infoteka, 1996.

- Smith-Rosenberg, Caroll. „The Female World of Love and Ritual“. Signs, I, № 1, (1975), 1-29.

- Спасовић, Ивана Б. Злата вредне: образовање женске деце у Јужном Банату од 1874. до 1918. године. Панчево: Историјски архив, 2014. 
- Спасовић, Ивана Б. Четврти сталеж: жена кроз историју. Прилози. Вршац: Висока школа струковних студија за васпитаче Михаило Палов, 2014.

- Спасовић, Ивана Б. Кнегиње и краљице династије Обреновић. Чачак: Пчелица, 2016.

- Спасовић, Ивана Б. Кнегиње и краљиие династије Карађорђевић. Чачак: Пчелица, 2016.

- Srbija u modernizacijskim procesima 19. i 20. veka. Položaj žene kao merilo modernizacije. Urednica Latinka Perović. Beograd: Institut za noviju istoriju Srbije, 1998.

- Станковић, Влада. „Питање укуса и морала у византијском друштву 12. века: сатирични приказ мушко-женских односа у песми Теодора Продрома и њено значење“. Годишњак за друштвену историју, XVIII, бр. 2, (2011), 7-19.

- Stansell, Christine. City of Women: Sex and Class in New York 1789-1860. New York: Alfred A. Knopf, 1986.

- Stearns, Peter N. European Society in Upheaval: Social History since 1750. New York: MacMillan Publishing Company, 1975.

- Stearns, Peter N. Gender in World History. London: Routledge, 2000.

- Stearns, Peter N., ed. Encyclopedia of European Social History from 1350 to 2000. New York: Charles Scribner's Sons, 2001.

- Stearns, Peter N. Consumerism in World History: The Global Transformation of Desire. London: Routledge, 2001.

- Stearns, Peter N. Childhood in World History. New York: Routledge, 2005.

- Stearns, Peter N. World History in Brief. New York: Pearson/Longman, 2007.

- Stearns, Peter N. Sexuality in World History. New York: Routledge, 2009.

- Стефановић, Светлана. „Женски покрет о проблему брака, слободне љубави, сексуалног васпитања, проституције и контроле рађања“. Годишњак за друштвену историју, V, бр. 1-3, (1998), 66-84.

- Stefanović, Svetlana. „Žensko pitanje u beogradskoj štampi i periodici 19181941“. Magistarski rad, Univerzitet u Beogradu, Filozofski fakultet, 2000.

- Столић, Ана. Краљица Драга. Београд: Завод за уџбенике, 2009.

- Столић, Ана. Сестре Српкиње: појава покрета за еманципацију жена и феминизма у Краљевини Србији. Београд: Еволута, 2015.

- Шкодрић, Љубинка. Положај жене у окупираној Србији 1941-1944. Докторска дисертација, Универзитет у Београду, Филозофски факултет, Одељење за историју, 2015.

- Šmale, Volfgang. Istorija muškosti u Evropi 1450-2000. Beograd: Clio, 2011.

- Štajn-Erlih, Vera. Porodica u transformaciji: studija u tri stotine jugoslovenskih sela. Zagreb: Naprijed, 1964.

- Tanahil, Rej. Čovek i seks. Beograd: Jugoslavija, 1981.

- Тимофејев, Алексеј. „Јагода на брези. Сексуална култура у Русији“. Годишњак за друштвену историју, XIX, бр. 3, (2012), 141-145.

- Тимотијевић, Мирослав. „Васпитање емоција и уобличавање модерног грађанског идентитета код Срба“. Годишъак за друштвену историју, XII, бр. 1$3,(2005), 7-24$. 
- Tomanović, Smiljka. Odrastanje u Beogradu: oblikovanje socijalnih biografija mladih u porodicama dva društvena sloja. Beograd: Institut za sociološka istraživanja, 2010.

- Vance, Carole S. Pleasure and Danger: Exploring Female Sexuality. New York: Routledge and Kegan Paul, 1984.

- Вучетић-Младеновић, Радина. Европа на Калемегдану. „Цвијета Зузорић“ и културни живот Београда 1918-1941. Београд: Институт за новију историју Србије, 2003.

- Вујачић, Видак. Трансформација патријархалне породице у Црној Гори. Београд: Слово љубве, 1977.

- Вујковић, Сарита. У грађанском оделу. Идентитети жена босанскохериеговачке грађанске културе 1878-1941. Београд/Бања Лука: Културни центар Београда, Музеј савремене умјетности Републике Српске, 2010.

- Вукићевић, Драгана. „Интимни свет у мемоарској прози 18. века“. У: Наука и традииија. Уредник Владимир Милисављевић, 347-358. Пале: Филозофски факултет, 2013.

-Vukićević, Dragana. „Kako reći i izbeći - erotska književnost u srpskoj nauci o književnosti“. U: Riječki filološki dani. Uredila Estela Banov, 261-270. Rijeka: Filozofski fakultet, 2014.

- Вукосављевић, Сретен. Историја сељачког друштва, V, Сеоске заједнице и облищи понашања у њима. Београд: Службени гласник, 2012.

- Вулетић, Александра. Породица у Србији средином 19. века. Београд: Историјски институт, Службени гласник, 2003.

- Вулетић Александра, и Јасна Мијаиловић. Између посела и балова. Живот у Србији у 19. веку. Београд: Завод за уџбенике, 2005.

- Вулетић, Александра. Брак у Кнежевини Србији. Београд: Завод за уџбенике, 2008.

-Weeks, Jeffrey. Coming Out: Homosexual Politics in Britain from the Nineteenth Century to the Present. London: Quartet, 1977.

-Weeks, Jeffrey. Sex, Politics, and Society: The Regulation of Sexuality Since 1800. London: Longman, 1981.

- Weeks, Jeffrey. Sexuality. London: Tavistock, 1986.

-Wilson, Michael L. „Thoughts on the History of Sexuality“. The William and Mary Quarterly, LX, № 1, (2003), Sexuality in Early America, 193-196.

- Vukićević, Dragana, „Erotsko kriptogramsko pismo i patrijarhalni svet“, (rukopis predavanja).

- http://clio.rs/edicije.php (pristupljeno 1. 6. 2017)

- http://www.udi.rs/about.asp (pristupljeno 1. 6. 2017) 
Predrag J. Marković

\author{
HISTORIOGRAPHY AND SEXUALITY: \\ AN OUTLINE FOR A HISTORY OF A DISCIPLINE
}

\title{
Summary
}

In Serbian historiography history of sexuality developed within (or together with) gender history. Along with several rare exemptions, both disciplines emerged during the 1990's. As for history of sexuality, the first wave of studies dealt with medical and legal issues, such as abortion, divorce and prostitution. The similar development could be traced in other historiographies. This thematic disbalance derived partly from the nature of the first discovered sources (public health institutions, courts, police documentation). In the 21 st century, history of sexuality flourished, as well as gender history, and for that matter, all other kinds of social history. Especially after 2010, relatively many published works dwelled on the LGBTQ topics. However, synthetic works such monographs are still missing.

KEYWORDS: Historiography, Gender history, Sexuality, Methodology

\section{GESCHICHTSSCHREIBUNG UND SEXUALITÄT (GESCHLECHTLICHKEIT): DIE SKIZZE FÜR GESCHICHTE EINER DISZIPLI}

\section{Zusammenfassung}

In der serbischen Geschichtsschreibung entwickelte sich die Geschichte der Sexualität (Geschlechtlichkeit) innerhalb und mit der Geschlechtergeschichte. Mit wenigen seltenen Ausnahmen sind die beiden Disziplinen in den neunziger Jahren des 20. Jahrhunderts entstanden. Soweit es die Geschichte der Sexualität angeht, beschäftigte sich "die erste Welle" der Arbeiten mit den medizinischen und rechtlichen Fragen wie Abtreibung, Scheidung und Prostitution. Eine ähnliche Entwicklung kann in einer anderen Geschichtsschreibung verfolgt werden. Dieses thematische Ungleichgewicht ergibt sich zum Teil aus der Natur der ersten entdeckten Quellen (Dokumente der öffentlichen Gesundheitseinrichtungen, der Gerichte und der Polizei). Im 21. Jahrhundert entfaltete sich die Geschichtsschreibung der Sexualität (Geschlechtlichkeit), ebenso wie die Geschichte der Menschheit und alle anderen Arten der Gesellschaftsgeschichte. Es gab viele Arbeiten, vor allem nach dem Jahr 2010, die den LBTTQ Themen gewidmet sind. Allerdings fehlen die Synthesen in diesem Bereich.

SCHLÜSSELWORTER: Historiographie, die Geschichte von Geschlecht, Sexualität, Methodik 